\title{
SOME PARASITIC CAUSES OF DIARRHEA IN CALVES AT BEHERA GOVERNORATE
}

\author{
REDA SAMIRAHMED FADLY \\ Animal Health Research Institute, Damanhour Branch.
}

\section{ABSTRACT}

Received at: 29/5/2012

Accepted: 14/7/2012
Three hundered faecal samples from diarrheic calves were examined using concentration flotation technique using saturated salt solution to detect Eimeria Spp.Oocysts and using Sheathers solution to detect Giardia species, Modified ZiehlNeelsen staining technique to detect Cryptosporidium parvum. The results indicated that $158(52.66 \%)$ were postive for protozoal parasites as Eimeria species (27\%), Cryptosporidium parvum (14.66\%) and Giardia species (11\%). Parasitological examination revealed that isolated five species of Eimeria in calves were E.bovis, E.zuernii, E.subspherica, E..cylindrica and E.ellipsiodalls. E. bovis and E.zuernii $(27.1 \%)$ and $(23.4 \%)$ were the most prevalent species infecting calves followed by E.subspherica (14.8\%), then E.ellipsoidalis (13.5\%) finally E. cylindrical $(9.8 \%)$. Eimeria Oocysts were demonstrated in all age groups of animals. However, it was evident that the prevalence of the disease was significantly higher in 16-20 weeks old (46.6\%). While Cryptosporidium parvum Oocysts was found to be decreased with increasing age of calves. It was found the most affected age group was between 1-4 weeks old (32\%) and Cysts of Giardia spp. were found to be higher at age group 4-8 weeks old (30\%). Seasonality over all prevalence of Eimeria spp., Cryptosporidium parvum and Giardia spp. was higher in samples taken during winter than samples taken during summer.

Key words: Eimeria spp., cryptosporidium, diarrhea in calves.

\section{INTRODUTION}

The most important cause of calf morbidity and mortalilty is diarrhea (Heat, 1992), Neonatal calf diarrhea continues to be the $1^{\text {st }}$ cause of calf mortality in Egypt which ranges between $27.4-55 \%$ of the total death in young calves (Ahmed, 1980).

Cryptosporidium, Giardia and Eimeria species are among the most common and important enteropathogens in calves (Maddox - Hyttel et al., 2006; Bartles et al., 2010). The most important clinical sign they may cause is watery diarrhoea, occasionally contaning blood in Eimeria infection. Other less obvious signs are fatigue, fever and reduced appetite (Fitzgerald, 1980). High infection rate, and lack of preventive and therapeutic measures when clinical disease manifests, can lead to out breaks and high mortality among calves. Moreover, the sub clincial effects of infection, which often result in recovery but lower weight gain, are also important to animal health and productivity (Daugschies et al., 1986). Bovine coccidiosis has a world wide distribution and result in economical losses. More than twelve different species of Eimeria in cattle and buffalo have been documented up till now (Abebe et al., 2008).

Most commonly pathogenic species are $E$. bovis and E.zuernii causing mortality and morbidity by disturbing absorption mechanisms (Cicek et al., 2007).

Coccidiosis in cattle is observed in all age groups but it is most common and important in young animals, in associations with other entropathogens coccidia have been indicated as an important cause of diarrhea in calves. Cryptosporidium parvum, first reported as entero pathogen in a calf (Panciera et al., 1971), has now been reported as prevalent and wide spread in calves from 4 days to 4 weeks of age by numerous investigators in many countries. Clinical neonatal bovine Cryptosporidiosis is usually a result of infection with $C$. parvum. Cryptosporidium has direct life cycle which is completed in 3 days and transmission is fecal - oral. Cryptosporidiosis is considered to be zoonotic disease (Miron, 1991) and the most common route of infection in close contact with diarrheic feces. Due to the limited availability of effective drugs the control of Cryptosporidiosis relies mainly on hygienic measures and good management (De Graaf et al., 1999).

Giardia intestinalis (synomyms G. duodenalis and G. lamblia) is globally distributed and is a common protozoon parasite in many species of animals and man. The public health implication of Giardiasis are well known and it's effect on calf performance is not conclusive. The earliest reports of Giardia were in India and Egypt were made by (Deshpande and 
Shostri, 1981) and (Suvillan et al., 1988)

There is a close association between the prevalence of the Cryptosporidium and Giardia infection and age of animal (Lassen, 2011).

The aim of this study was to:

1- Estimation the prevalence, age and seasonal distribution of Cryptosporidium, Giardia and Eimeria infection among calves.

2- Identification of various species of Cryptosporidium, Giardia and Eimeria affecting calves.

\section{MATERIALS and METHODS}

1- Animals: a total number of 300 fecal samples from cow calves from May 2011 to April 2012 were collected from different localities in Behera Governorate. Calves aged from 1 week to 20 weeks.

2- Samples: faecal samples were collected directly from the rectum using plastic hand gloves, each glove being marked to indicate animals number age and date of sampling.

\section{Parasitological Examination.}

1- Concentration flotation technique: according to Soulsby (1982), using saturated salt solution for detction of Eimeria spp. oocysts and Sheathers solution for detction of Giardia spp.cysts.

2- Sporultion of Eimeria species oocysts: according to Soulsby (1982) the positive fecal samples were sporulated using $2.5 \%$ potassium dichromate solution for one week.

3- Modified Ziehl- Neelsen staining technique (MZN): was used for diagnosis of Cryptosporidium parvum oocyst according to Henriksen and Pohlenz (1981). Thin fecal smears were prepared on glass slides, dried at room temp., fixed in methanol $96 \%$ for 2-5 min., then fixed in flame samples were stained in concentrated carbol fuchsin for 20-30 min. The discoloration procedure was realized with $3 \%$ hydrochloric acid for 20-60 seconds, then smears were washed with running water and counter stained with solution of malachite green for 3- $5 \mathrm{~min}$. rinsed in tap water and air dried.

4- Cysts of Giardia were found by floating the sample in Sheathers solution which has been found superior in getting Giardia Cysts to float, dropwise application of dilute Lugol's iodine solution (10.5\%) to facilitate microscopic examination of Giardia according to Levine (1985).

5- Smears were examined under light microscope with $\mathrm{x} 40$ and $\mathrm{x} 100$ magnifications, Non sporulated respectively.

oocysts, sporulated oocysts and cysts size were measured using bright field microscopy with a calibrated eye piece micrometer.

6- Identification of different oocysts \& Cysts, according to Levine (1985).

\section{RESULTS}

Prevalence of Cryptosporidium oocyst, Giardia cyst. and Eimeria oocysts:

As shown in Table (1) out of the examined 300 faecal samples from diarrheic calves 158 (52.66\%) were positive for oocysts of total Eimeria spp., total Cryptosporidium parvum and total Cysts of Giardia spp. 27\%, 14.66\% and 11\%. Table (2) Parasitological examination revealed that isolated five species of Eimeria in calves were E.bovis, E.zuernii, E.subspherica, E.cylindrica and E.ellipsoidalis. The most prevalent species infecting calves were E.bovis and E.zuernii (27.1\%), (23.4\%) followed by E.subspherica (14.8\%) and E.ellipsoidalis (13.5\%) respectively. The lowest prevalent was E.cylindrica (9.8\%). Mixed infection involved two or three Eimeria species was observed in $11.11 \%$ of the samples.

Table (3) Eimeria oocysts were demonstrated in all age groups of animals. However, it was evident that the prevalence of the disease was significantly higher at $16-20$ ws (46.6\%). While Cryptosporidium parvum appeared to be inversely related to age, where the prevalence of oocysts was found to be decreased with increasing age of calves. It was found the most affected age group was between 1-4 ws (32\%). Cysts of Giardia spp. were found high at age group 4-8 ws (30\%). Table (4) for seasonal variations reveal that over all prevalence of Eimeria spp., Cryptosporidium parvum and Giardia cysts, was higher in samples taken during winter than samples taken during summer.

\section{Morphology of Cryptosporidium oocyst, Giardia cyst.and Eimeria oocysts:}

Fig. (1) Microscopical examination of Acid-fast stained smears revealed ovoid oocysts of Cryptosporidium, measured of 4-6 um in diameter. The oocysts were spherical to ovoid in shape stained red to pink with granular appearance against green back ground.

Fig (2). Microscopical examination of iodine stained smears revealed Giardia cyst is oval cyst measured 7-11 um long and 7-9 um wid and a 0.3 um thick outer wall of cystic wall internally there are four nuclei. Figs (3-7) represent non sporulated and sporulated oocysts of Eimeria spp. 
Assiut Vet. Med. J. Vol. 58 No. 134 July 2012

Table 1: Incidence of Protozoan Parasites Infect Calves at Behera Governorate.

\begin{tabular}{|c|c|c|c|c|c|c|c|c|c|c|c|c|c|c|c|}
\hline \multirow{2}{*}{$\begin{array}{l}\text { No. Of } \\
\text { Ex. } \\
\text { calves }\end{array}$} & \multicolumn{2}{|c|}{$\begin{array}{l}\text { Single } \\
\text { Eimeria } \\
\text { spp. }\end{array}$} & \multicolumn{2}{|c|}{$\begin{array}{l}\text { Single } \\
\text { Crypto. } \\
\text { Spp. }\end{array}$} & \multicolumn{2}{|c|}{$\begin{array}{l}\text { Single } \\
\text { Giardia } \\
\text { Spp. }\end{array}$} & \multirow{2}{*}{$\begin{array}{c}\text { Mixed infection } \\
\text { Eimeria }+ \text { Crypto } \\
\text { (2) }\end{array}$} & \multicolumn{2}{|c|}{$\begin{array}{c}\text { Total } \\
\text { Eimeria }\end{array}$} & \multicolumn{2}{|c|}{$\begin{array}{c}\text { Total } \\
\text { Crypto. }\end{array}$} & \multicolumn{2}{|c|}{$\begin{array}{c}\text { Toal } \\
\text { Giardia }\end{array}$} & \multicolumn{2}{|c|}{$\begin{array}{l}\text { Total } \\
\text { infec. } \\
\text { Calves }\end{array}$} \\
\hline & No & $\%$ & No & $\%$ & No & $\%$ & & No & $\%$ & No & $\%$ & No & $\%$ & No & $\%$ \\
\hline 300 & 75 & 25 & 39 & 13 & 27 & 9 & $\begin{array}{c}\text { Eimeria }+ \text { Giardia } \\
\text { (3) }\end{array}$ & 81 & 27 & 44 & 14.66 & 33 & 11 & 158 & 52.66 \\
\hline & & & & & & & $\begin{array}{c}\text { Eimeria }+ \text { Giardia } \\
+ \text { Crypto (1) } \\
\text { Giardia }+ \text { Crypto } \\
\text { (2) }\end{array}$ & & & & & & & & \\
\hline
\end{tabular}

Table 2: Prevalence and Characters of Different Eimeria spp. Isolated from Calves

\begin{tabular}{ccccccc}
\hline Eimeria spp. & No. & $\%$ & Shape & Size um & Micropyle & $\begin{array}{c}\text { Sporulation } \\
\text { Time days }\end{array}$ \\
\hline E.bovis & 22 & 27.1 & Ovoid & $27 \times 20.3$ & Present & $2-3$ \\
\hline E.zuernii & 19 & 23.4 & Spherical & $17.8 \times 15.6$ & No & $2-3$ \\
\hline E.subspherica & 12 & 14.8 & Round or Subspherical & $11 \times 10.4$ & No & $4-5$ \\
\hline E. cylindrica & 8 & 9.8 & Cylindrical & $15 \times 12$ & No & $2-3$ \\
\hline E.ellipsoidalls & 11 & 13.5 & Ellipsiod to slightovoid & $12 \times 8$ & No & $2-3$ \\
\hline Mixed in fection & 9 & 11.11 & & & & \\
\hline
\end{tabular}

Table 3: Prevalence of Different Protozoan lnfection in Relation to Age of Calves

\begin{tabular}{ccccccccc}
\hline \multirow{2}{*}{ Age } & No. of exam calves & \multicolumn{2}{c}{ Eimeria } & \multicolumn{2}{c}{ Cryptosporidia } & \multicolumn{2}{c}{ Giardia } \\
\cline { 3 - 8 } & & No. & $\%$ & No. & $\%$ & No. & $\%$ \\
\hline $1-4 \mathrm{ws}$ & 50 & 7 & 14 & 16 & 32 & 3 & 6 \\
\hline $4-8 \mathrm{ws}$ & 50 & 8 & 16 & 14 & 28 & 15 & 30 \\
\hline $8-12 \mathrm{ws}$ & 75 & 26 & 34.6 & 8 & 10.6 & 6 & 8 \\
\hline $12-16 \mathrm{ws}$ & 50 & 5 & 6.1 & 5 & 10 & 5 & 10 \\
\hline $16-20 \mathrm{ws}$ & 75 & 35 & 46.6 & 1 & 1.3 & 4 & 9 \\
\hline Total & 300 & 81 & 27 & 44 & 14.66 & 33 & 11 \\
\hline
\end{tabular}

Table 4: Seasonal Variations of Prevalence of Different Protozoal Infection

\begin{tabular}{cccccccc}
\hline \multirow{2}{*}{ Seasons } & \multirow{2}{*}{ No. of exam calves } & \multicolumn{2}{c}{ Eimeria } & \multicolumn{2}{c}{ Crypto. } & \multicolumn{2}{c}{ Giardia } \\
\cline { 3 - 8 } & & No. & $\%$ & No. & $\%$ & No. & $\%$ \\
\hline Spring & 75 & 12 & 16 & 8 & 10.6 & 3 & 4 \\
\hline Summer & 75 & 10 & 13.3 & 4 & 5.3 & 4 & 5.3 \\
\hline Autumn & 75 & 25 & 33.3 & 13 & 17.3 & 11 & 14.6 \\
\hline Winter & 75 & 34 & 45.3 & 19 & 25.3 & 15 & 20 \\
\hline
\end{tabular}




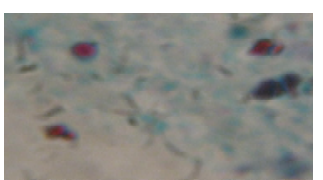

Fig ( 1$)$

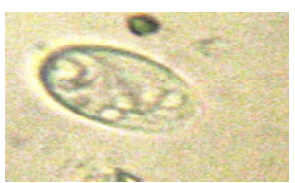

Fig ( 2 )

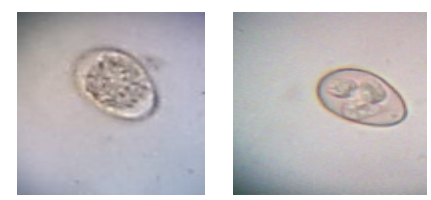

Fig ( 3 )

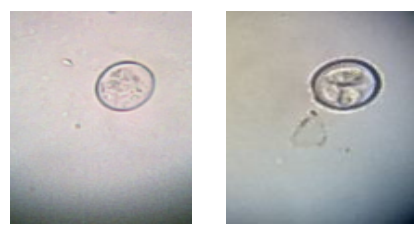

Fig ( 4)

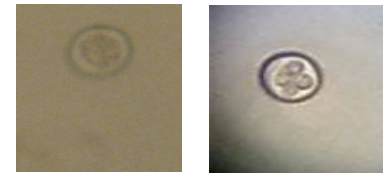

Fig ( 5 )
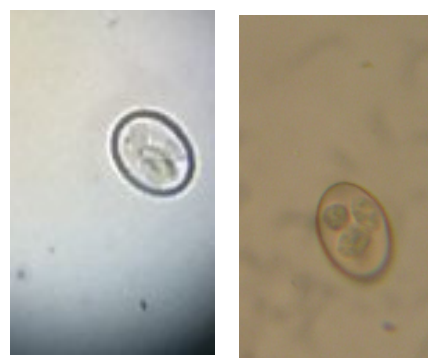

Fig ( 6 )

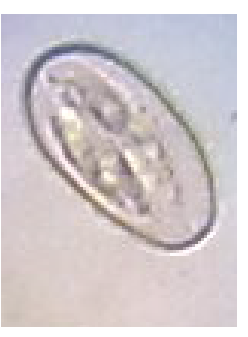

Fig ( 7 )

Fig (1) Oocysts of Cryptosporidium parvum stained with Modified Ziehl-Neelsen stain X100

Fig (2) Cysts of Giardia spp.stained with iodine stain X40

Fig (3) Non sporulated and sporulated oocysts of E.bovis X40

Fig (4) Non sporulated and sporulated oocysts of E.zuernii X40

Fig (5) Non sporulated and sporulated oocysts of E.subspherica X40

Fig (6) Non sporulated and sporulated oocysts of E.cylindrica X40

Fig (7) Sporulated oocysts of E.Ellipsoidalis X40 


\section{DISCUSSION}

Cryptosporidium, Giardia and Eimeria infections have been reported from calves in many parts of the world (Hamnes et al., 2006).

The parasitological examination as shown in Table (1) revealed that $158(52.66 \%)$ of calves examined were infected with one or more parasitic protozoan agents. The result of this study confirmed the fact that, protozoal infection were wide spread in diarrhoeic calves, this is in accordance with previous studies (Goz. et al., 2006 and Gul et al., 2008) in Turkey.

Eimeria oocysts were identified in $(27 \%)$ calves, these results are nearly to that recorded by Gul et al. (2008) $22.53 \%$ in Turkey. Over all prevalence of Eimeria in present study is lower than perivously reported by Gasmir et al. (2011) 47.59\% in Sudan and Yu et al. (2011) 34. 94\% in China while our results was higher than this reported by El. Sheriff et al. (2000) $12.05 \%$ in Egypt. This variation is most likely attributed to the differences in management and hasbandry practice of the study animals in different countries. Table (2) Five Eimeria species were identified in calves in this study namely $E$. bovis, E.Zuernii, E. Subspheica, E. cylindrica and E. ellipsoidalis, similar number of species has been described in surveys performed by El Sheriff et al. (2000) and Mary (2003).

Table (2) demonstrared that the prevalence of $E$. bovis and E zuernii, $(27.1 \%)$ and (23.4\%) which are most prevalent species for calves this concurs with the findings of Harfoush et al. (2005), Cicek et al. (2007), Abebe et al. (2008) and lassen et al. (2011).

Table (4) The prevalence of Eimeria spp. oocysts were highest in the age group of the 16-20 weeks old, this results were in accordance with the finding of Cicek et al. (2007); Abebe et al. (2008) and Priti et al. (2008), this data is in contrast with Sanchez et al. (2008) who found high percentage of infection 21-45 day.

Seasonal prevalence of coccidiosis among calves was higher in Winter (45.3\%) Followed by Autumn (33.3\%), Spring (16\%) and Summer (13.3\%) Table (4). Similar results were recorded by El Sheriff et al. (2000) and Mary (2003) in Egypt who reported higher prevalence during month of rain, while Sanchez et al. (2008) found that highest incidence in spring and autumn than winter and summer. This difference may be due to the different localities, seasonal and climate variation.

Cryptosporidium and Giardia infections have been reported for cattle in many parts of the world, prevalence data have often varied markedly. The high prevalence of Cryptosporidium and Giardia in neonates and young calves is well known and unambiguously age dependent (Xiao and Herd 2004). The findings of the present study showed of Cryptosporidium.oocysts were identified in (14.66\%) in neonat calves by Modified Ziehl Neelsen staining technique, these results were relatively Similar to the values recorded by EL-Shemy, (2006), El.Khodery and Osman (2008), Amal and Reda (2009) and El Kelesh et al. (2009) (14\%,14.19\%, 14\% and 14\%). While our result is relatively lower than the values recorded by, El sherif et al. (2000) $21.92 \%$ and Majeed et al. (2011) 38.8\% Table (1). On other hand our result was higher that obtined by Cokline et al. (2009) 6.2\%. These differences might be attributed to the difference in localities, breeding and management system. Cryptosporidium oocysts were found in all age categories but with high prevalence in $1-4 w s$ $(35 \%)$, these results revealed that Cryptosporidios is a disease of young ages and gradual decrease of infection rate occuared with age progression, these finding were emphasized by Bartels et al. (2010). Mean while, O'Handley et al. (1999) stated that Cryptosporidium was important pathogen when calves were less than one month, also EL Sherif et al. (2000); El. Dessouky and Nabila (2005); Amal and Reda (2009) and Majeed et al. (2011) said that calves less than one month recorded the highest degree of infection.

As shown in Table (4), the highest incidence of infection was recorded in winter $(25.3 \%)$, followed by spring (17.3\%), autumn (10.8\%) and summer 8\%, Bendali et al. (1999) and Lefay et al. (2001) found that the highest incidence of Cryptosporidiosis was in winter and lower infection rate was in summer.

From the presnt study Giardia spp.cysts were identified in $(9 \%)$ of calves, these result was similar to Iburg et al. (1996) 10.4\% in Denmark and Gul et al. (2008) 9.3\%, While higher result observed by, Ruest et al. (1998) 26.6\% in swedan, and Olson et al. (2004) $73 \%$ British Columbia, While lower result observed by Xiao (1994) 5.6\% These difference may be due to the different localities, seasonal and climate variation Table (1).

This highest rate of prevalence of Giardia in the age group of the 4-8 weeks old these result similar to Davoudi et al. (2011) who found the highest dgree of infection in 8 weeks old 54.38\% Table (3). Seasonal prevalence of Giardia among calves highest rate of incidence was detected in winter season $(20 \%)$ this result agree with Misic et al. (2006) and this result disagree with Davoudi et al. (2011) who found the highest degree of incidence was in summer(37.6\%) and least incidence was in winter $(16.8 \%)$ These differences might be attributed to the difference in localities, breeding and management system Table (4).

\section{CONCLUSION}

This study reveals that cryptosporidium spp., Giardia spp., and Eimeria spp., are the most Frequent parasites in calves at Behera Governorate These infections play an important role in animal production as it has been demonstrating that these parasites are able to cause diarrhea which negatively inflnuce growth,impair feed conversion and reduce milk production. 
Giardia and Cryptosporidium may also act as an infection source for humans by direct contact with contaminated faces or water.

\section{REFERENCES}

Abebe, R.; Wossene, A. and Kumsa, B. (2008): Epidemiology of Eimeria infections in calves in Addis Ababa and Debre Zeit dairy farms, Ethiopia. Intern. J. Appl. Res. Vet. Med 6: 2430.

Amal, A.E. and Reda, S.F. (2009): Studies on Cryptosporidium infection in calves in Behera Province. EVMSPJ, 5:37-47.

Ahmed, A.A. (1980): Calf scoures in Egyptian buffalo - Cows. Egyptian German Seminar on the Mortality of Newly Born Calves: 19-21.

Bartels, C.J.; Holzhausr, M.; Jorristma, R.; Swart, W.A. and Lam, T.J. (2010): Prevalence, prediction and risk factors of entero pathogens in normal and non - normal faces of young Dutch dairy calves. 93: 162-169.

Bendali, F.; Sanaa, M.; Bichet, H. and Schelcher, F. (1999): Risk factors associated with diarrhoea in newborn calves. Veterinary Research 30: 509-522.

Cicek, H.; Sevimlig, F.; Kozan, E.; Kose, M.; Eser, M. and Dogan, N. (2007): Prevalence of Coccidian in beef cattle in Western Turkey. Parasitol. Res., 101: 1239-1243.

Cokline, T.; Uehinger, F.D.; Farber, J.M.; Barkema, H.W.; O'handley, R.M. and Dixon, B.R. (2009): Prevalence and molecular characterization of Cryptosporidium spp. in diary calves from 11 farms in PrinceEdward Island, Canada. J. Vet. Parasitol. 160: 323-326.

Daugschies, A.; Akimaru, M. and Burger, H.J. (1986): Experimentelle Eimeria bovis - infektionen beim kalb: 1. Parasitologishche und Klinische Befumle. Dtsch. Tieraztle. wschr., 93: 393397.

Davoudi, Y.; Garedaghi, Y. and Safarmashaei, S. (2011): Epidemiological study of Giardiasis in Diarrheic calves in East-Azerbaijian Province, Iran. J. Aim. Vet. Adv., 10: 2508-2510.

De Graaf, D.C.; Vanopdenbosch, E.; Ortega-More, L.M.; Abbassi, H. and Peters, J.E. (1999): A review of the importance of Cryptosporidiosis in farm animals. int. J. parasitol., 29: 12691287.

Deshpande, P.D. and Shostri, U.V. (1981): Incidence of Giardia infection in calves in Mahashira state, India Trop. Anim. Health prod., 13: 43.

El. Dessouky, S.A. and Nabila, M.E. (2005): Effect of Cryptosporidium parvum infection on the haematological and blood biochemical changes of buffalo calves with special reference to prevalence of infection among buffaloes. Assiut Vet. Med. J., 51: 108-123.

El. Kelesh, E.A. Abdel-Maogood, S.Z. and AbdelWahab, A.M. (2009): Comparative studies on some cryptosporidium species infecting different animals. EVMSPJ, 5: 37-47.

El Khodery, S.A. and Osman, S.A. (2008): Cryptosoridiosis in buffalo calves (Bubausbubalis): Prevalence and potential risk factors. Top. Ainm. Hlth. pred., 40(6): 419-426.

El Shemy, T.M. (2006): Recent advances in diagnosis and treatment of neonatal calf diarroea. $\mathrm{PhD}$ thesis, Fac. Vet. Med., Alex. Univ.

El Sherif, A.M.; Abed ElGawad, M.A.A.; Lotfy, H.S. and Shokier, K.A.M. (2000): Impact of gastrointestinal nematodes and some enteric protozoal affections on the health of buffalo calves. Assiut Vet. Med. J., 43(86): 260-270.

Fitzgerald, P.R. (1980): The economic impact of coccidiosis in domestic animals. Adv. Vet. Sci Comp. Med., 24: 121-143.

Gasmir, G.S.; Osman, A.Y.; El-Amin, F.A. and Halima, L.O. (2011): A survey of enteric Coccidia of cattle in the sudan. Sudan J. Vet. Res., 15: 43-48.

Goz, Y.; Atug, N.; Yuksek, N. and Ozkan, C. (2006): Parasites detected in neo natal and young calves with diarrhea Bull. Vet. Inst. Pulawy, 50: 345-348.

Gul, A.; Cicek, M. and Kilinic, O. (2008): Prevalence of Eimeria spp., Cryptosporidium spp. and Giardia spp. in calves in the Van province. Trukiye Parazitol Derg., 3: 202-204.

Hamnes, I.S.; Gjerde, B. and Robertson, L. (2006): Prevalance of Giardia and Cryptosporidium in dairy calves in three areas of Norway. Vet. Perasitol., 140: 204-216.

Harfoush, A.M.; Soliman, A.H. and Amer, A.S. (2005): Some studeies on coccidiosis in calves and lambs in Kafr El-Sheikn Governorate. EVMSPJ, 2: 250. 261.

Heat, S.E. (1992): Neonatal diarrhea in calves: diagnosis and investigations in problems herds. Compend contin. Educ. Pract. Vet.,14: 9951002.

Henriksen, S.A. and Pohlenz, J.F.L. (1981): Staining of cryptosporidia by a modified Ziehl Neelsen technique. Acta.Vet. Scand., 22: 594-596.

Hompson, R.C. (2000): Giardiasis as are - emerging infections disease and its zoonotic potential. Int. J. Parasitol., 30: 1259-1267.

Iburg, T.; Gasser, R.B. and Henriksen, S.A. (1996): First record of Giardia in cattle in Denmark. ActaVest Scand, 77: 337-341.

Lassen, B. (2011): The prevalences of Eimeria and Cryptosporidium in large Latvian cattle Herds. Vet. Med. Zoot., 54: 47-52.

Lefay, D.; Naciri, M.; Pairier, P. and Chermette, R. (2001): Prevalence of cryptosporidium infection in calves in France. Vet. Parasitol, 8: $1-9$.

Levine, N.D. (1985): Veterinary Protozoology. Iowa StateUniversity Press. Ames p., 139.

Maddox-Hyttel, C.; Langkjaer, R.B.; Enemark, H.L. and Vigre, H. (2006): Cryptosporidum and 
Giardia in different age groups of Danish cattle and pigs: occurrence and management associated risk factors. Vet. Parasitol., 141: 48-59.

Majeed, H.A.; Maha, K.A.; Nadra Elwgoud, M.I.; El-Azazy, M.E.; Sami, M.A. and El Said, H. (2011): Infectous causes of neonatal diarrhea in cattle in Kuwait with special refernce to cryptosporidiosis J. of Anim and Vet. Advances., 17: 2282-2286.

Mary, B. (2003): Anticoccidial effects of clindamycin and chloramphenicol on bovine Eimeria. EVMSPJ, 1: 13-27.

Matjila, P.T. and Penzhorn, B.L. (2002): Occurance and diversity bovine Coccidian at three localities in South Africa. Vet. Parasitol, 2: 93-102.

Miron, D. (1991): Calves a source of an out break of cryptosporidiosis among young children in an agricultural close community pediatric Infec. Dis. J., 10: 438-441.

Misic, Z.; Katic, R.S. and Kulisic (2006): Cryptosporidum infection ln lambs and goats in Serbia. Acta veterinaria, 56, (1): 49-54.

O'Handley, R.M.; Cockwill, C.; Mcallister, T.A.; Jelinski, M.D.; Morck, D.W. and Olson, M.E. (1999): Duration of naturally acquired giardiosis and cryptosridiosis in dairy calves and their association with diarrhea. J. Am. Vet. Med. Assoc., 214: 391-396.

Olson, M.E.; O'Handley, R.M.; Ralston, B.J.; McAllister, T.A. and Thompson, R.C. (2004): Update on Cryptosporidium and Giardia infections in cattle. Trends parasitol., 20: 185-191.
Panciera, R.J.; Thomassen, R.W. and Garner, F.M. (1971): Cryptosporidial infection in a calf. Vet Pathol., 8: 479-484.

Priti, M.; Sinha, S.R.; Sucheta, S.; Verma, S.B.; Sharma, S.K. and Mandal, K.G. (2008): Prevalence of bovine coccidiosis at Patna. J. Vet. Parasitol 22: 5-12.

Ruest, N.; Faubert, G.M. and Couture, Y. (1998): Prevalence and geographic distribution of Giardia spp and Cryptosporidium spp in dairy farms In Quebec. can. Vet. J., 39: 697-700.

Sanchez, R.O.; Romero, J.R. and Founroge, R.O. (2008): Dynamics of Eimeria oocyst excretion in dairy calves in the province of Buenos Aire (Argentina), during their first 2 months of age. Vet. Parasitol., 151: 133-138.

Soulsby, J.L. (1982): Helminthes, Arthopods and protozoa of domesticated animals $6^{\text {th }}$ ed. published by Balliere Tindall and cassel L T.d London.

Suvillan, P.S.; Dupont, H.I.; Arafat, R.R.; Thorton, S.A; Selwyn, B.J.; Elalamy, M.A. and Zaki, A.M. (1988): Illness and reservoirs associated with Giardia lamblia infection in rural Egypt: the case against treatment in devolping world environment Am. J. Epidem., 127: 1272-1281.

Xiao, L. (1994): Giardia infection in farm animals. Parasitol., Today, 10: 436-438.

Xiao, L. and Herd, R.P. (2004): Infection pattern on Cryptosporidium and Giardia in calves. Vet. Parasitol., 55: 257-262.

Yu, K.S.; Gao, M.; Huang, N.; Jia, O.Y. and Line, Q. (2011): Prevalence of Coccidial infection in cattle in Shaanxi Province, NorthWestern China. J. Anim. Vet. Adv, 20: 2716-2719.

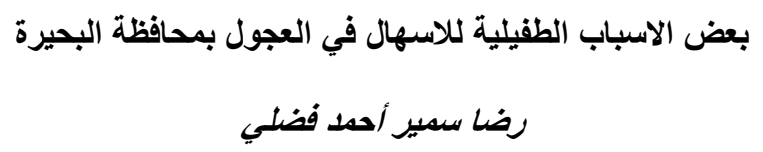

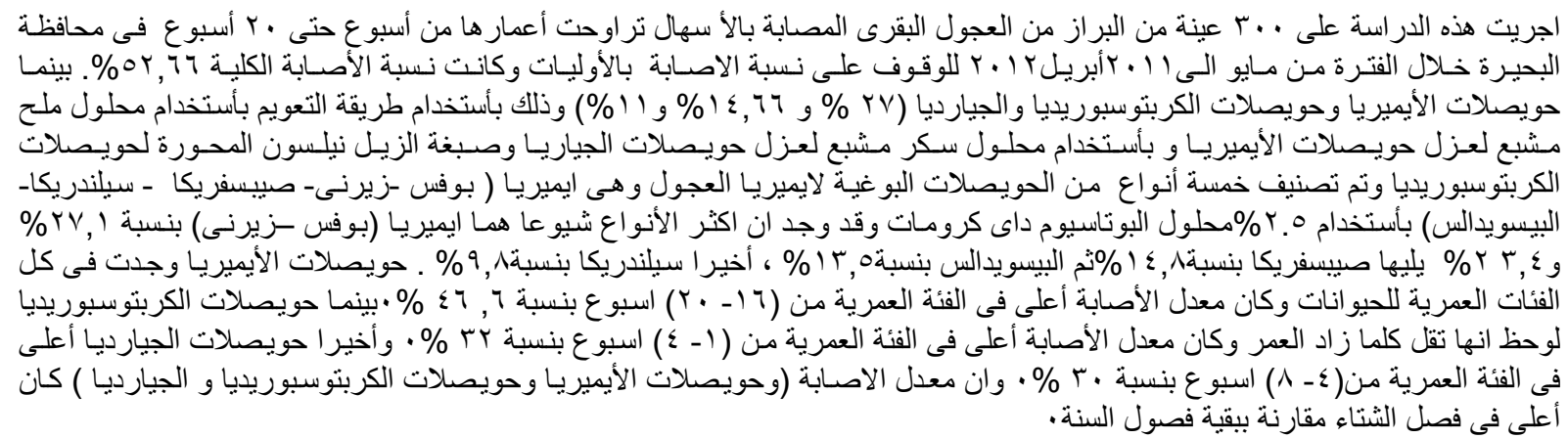

